\title{
機能的電気刺激による神経筋接合部の変化についての検討
}

野 村 研一郎・片 田 彰 博 $\cdot$ 國 部勇・太田亮
原 㴊 保 明

\section{Effects of Electrical Stimulation on Neuromuscular Junctions in Denervated Muscles}

\author{
Kenichiro Nomura, Akihiro Katada, Isamu Kunibe, \\ Ryo Ota and Yasuaki Harabuchi
}

\begin{abstract}
Functional electrical stimulation (FES) has been proposed as a potential treatment for restoring the motor functions of denervated motor systems. Furthermore, FES on denervarted muscle has the potential to prevent muscle atrophy and promote reinnervation.

In this study, to assess these effects of FES, we evaluated what kind of changes occurred in neuromuscular junctions (NMJ) by FES to muscle after denervation. Tibialis anterior muscles of rats were used for this study. A sciatic nerve anastomosis was performed after having cut off the nerve. We applied electric stimulation $(2 \mathrm{~Hz}, 0.5 \mathrm{~ms}, 4.0 \mathrm{~mA})$ three days a week to the rats. Electric stimulation was performed using surface electrode percutaneously for an hour. The rats were euthanized 2, 4 or 8 weeks after treatment. To evaluate the number of axon nerve terminals and acetylcholine receptors (AchRs), synaptic vesicles of the nerve endings were labeled using antisynaptophysin antibody and AchRs were labeled by a -Bungarotoxin. We analyzed the effects of FES by counting the number of AchRs and axon nerve terminals. The number of AchRs decreased slightly after denervation for the group that did not receive electrical stimulation; whereas, the group that did have electrical stimulation to the denervated muscles increased the number of AchRs. After denervation the number of nerve terminals decreased at once and gradually increased according to completion of reinnervation. Electrical stimulation promoted regenerating nerve terminals during the reinnervation process. From the results of this study, we confirmed that electrical stimulation promoted regenerating NMJ during reinnervation process.
\end{abstract}

Key words：反回神経麻瘏，筋萎縮，機能的電気刺激，神経筋接合部

\section{は じめに}

反回神経麻痺による喉頭の運動機能の障害は, 脱神経に よって内喉頭筋が収縮しなくなることに起因する. 一般的 に末梢神経は中枢神経と異なり神経再生が旺盛であるため, 支配神経が切断されたとしても，切断部位で神経吻合をお こなうことによって神経の再支配を誘導することが可能で ある. 兴のため, 腫瘍の切除などのために反回神経が切断 された場合には, 兴の後の内喉頭筋の神経再支配を期待し, 神経吻合や筋弁移植などが行われている．この再支配は筋 の廃用性萎縮を防ぐことに有効であるとの報告があるもの の，運動機能の回復については満足できる結果が得られな いことが多い. 兴の原因として内喉頭筋の神経再支配は作 用の異なる声門開大筋と声門閉鎖筋の光れ光れに選択的に 起こるわけではなく，作用の異なる筋に選択性のない過誤 支配が生じることが挙げられる.

近年, 脱神経により麻痺した筋に微小電気刺激を加え筋 収縮させることで失われた運動機能の回復を図る機能的電 気刺激 (functional electrical stimulation : FES) が注
目されており, 脳梗塞や脊髄損傷後の運動機能の回復に応 用されつつある. 我々はこれまで麻痺している喉頭の運動 機能を回復させる治療法の一つとして FES が応用可能で あるか検討を行ってきた ${ }^{1,2)}$. 兴の結果, 実験動物のレベ ルでは, 反回神経切断後の喉頭に電気刺激を用いて声門開 大運動や声門閉鎖運動を誘発することができ, 呼吸機能や 発声機能が改善することが確認されている ${ }^{2)}$.また, Zealear らは, 反回神経を切断し再吻合した後に, 後輪状 披裂筋を電気刺激し続けることで，単に声門開大運動を誘 発するだけではなく，筋の萎縮を抑制し，さらに選択的な 筋の神経再支配が誘導されることを報告した 神経後の筋に加える電気刺激が FES として運動機能を回 復させるだけではなく, 筋萎縮抑制, 神経再支配の誘導に も有効的な治療手段となる可能性を示唆するものである. しかし電気刺激が筋の神経再支配に及ぼす影響については まだまだ不明な点が多く, 神経再支配の選択性のみならず, 再支配を促進するのか否かについても多くの議論があると ころである. 今回我々は, 脱神経後の筋に加えた電気刺激 が神経再支配にどのような影響を及ぼすのか明らかにする

旭川医科大学耳鼻咽喉科・頭頸部外科学教室

Department of Otolaryngology- Head \& Neck Surgery, Asahikawa Medical College 
ために，ラットの下肢をモデルとして，神経切断後に吻合 を行い，筋の再支配を誘導する際に，再支配を受ける筋に 電気刺激を加え続けることによって，筋線維や再生する神 経終末にどのような変化が生じるのか解析した.

\section{方}

法

実験には成ラット (Sprague-Dawley rat 250〜300g， 51頭) を用いた. 動物モデルは以下の 3 群を作成した．1) 神経切断群, 19頭 (以下切断群と略す), 2 ) 神経切断後 に再吻合を行う群，17頭 (以下再吻合群と略す)，3) 再 吻合後に機能的電気刺激を加える群, 15 頭 ( 以下刺激群と 略す）の 3 群である. ラットはペントバルビタール腹腔内 投与にて麻酔後，右慰部に皮膚切開を加え右坐骨神経を露 出した. 切断群は, 右坐骨神経を切断後に再吻合を防ぐ為 に両端を 4-0 絹系にて結紮した. 再吻合群は, 神経切断 後即時に顕微鏡下で 9 - 0 ナイロンを用いて神経上膜を縫 合した. 刺激群は, 神経吻合後, 同日よりペントバルビター ル腹腔内投与での麻酔下で，表面電極を用いて，吻合部よ り尾側の下腿部に，振幅 $4.0 \mathrm{~mA}$ ，持続時間 $0.5 \mathrm{~ms}$, 頻度 2 $\mathrm{Hz}$ の電気刺激を 1 回 1 時間, 週に 3 日行った。关れ光れ の群とも神経切断後から 2 週後, 4 週後, 8 週後にペント バルビタール深麻酔下に両側の前脛骨筋を摘出した．筋肉 はイソペンタンと液体窒素を用いて凍結処理した後に, 筋 の中央部で筋線維にほぼ直行する方向で厚さ $8 \mu \mathrm{m}$ の切 片を作成した．筋線維の観察の為にへマトキシリン・エ才 ジン染色を行い, 光学顕微鏡下で連続した 2 枚の切片で10

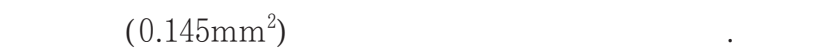
には画像解析ソフト (Adobe Photoshop, Image J) を 用い撮影した 2 枚の画像内に存在する筋線維数と平均の筋 線維断面積を求めた。 また同一個体の左側 (無処置側) の 筋も同樣に解析を行い, 弚れ光れの個体について無処置側 の平均断面積を $100 \%$ とした処置側の相対值を算出した.

筋線維断面積の変化

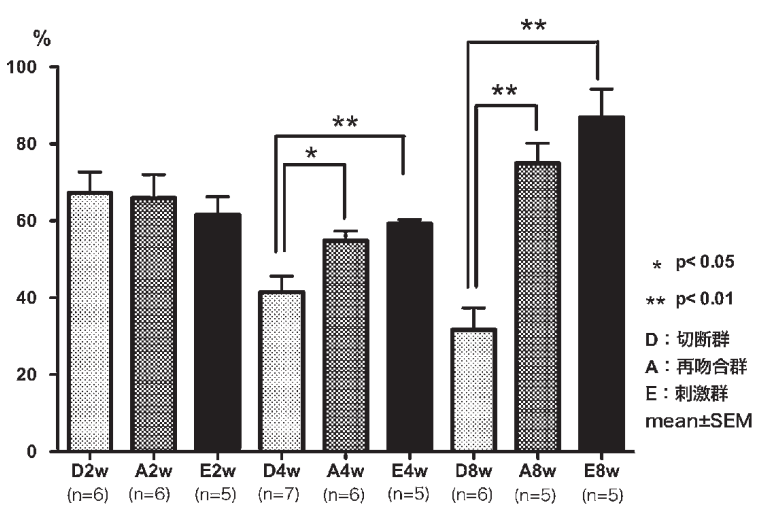

図 1 各群での脱神経 2 週後 $(2 \mathrm{w}), 4$ 週後 $(4 \mathrm{w})$, 8 週後 $(8 \mathrm{w})$ における処置側の筋線維断面積 を無処置側と比較した值 (処置側/無処置側) の変化

4 週後, 8 週後の切断群と比較して, 弚れ光れ 同週の再吻合群, 刺激群で有意差を認めた. ( unpaired $\mathrm{t}$ test)
神経終末とアセチルコリン受容体の観察には蛍光 2 重染 色法を用いた。神経終末に対しては，Fluorescein isothiocyanate (FITC) で標識した神経終末に存在する シナプス小胞の膜蛋白に対する抗体である抗 Synaptophysin 抗体 (PROGEN) を用いた. アセチルコ リン受容体に対しては, Rhodamine で標識したアセチル コリン受容体に高い親和性をもつへビ毒素であるa Bungarotoxin (Sigma) を用いた。連続した切片 4 枚で 蛍光顕微鏡下に切片全体に存在するアセチルコリン受容体 数, 神経終末数を数え, 兴の平均值を求めた. 個体により 切片面積, 筋線維数が異なるため筋線維数当たりの値を算 出し検討を行った.

$$
\text { 結果 }
$$

\section{1. 筋線維断面積の変化}

2 週後には 3 群とも健側に比較して $60 \%$ 程度の断面積の 減少を認めた. 切断群では 4 週後には $42 \%, 8$ 週後には32 \%とさらなる減少を認めた. 一方で再吻合群と刺激群では 4 週後から回復傾向を認め, 光れ光れ $55 \%$, $59 \%$ と両者と も切断群と比較して有意な回復を認めた． 8 週後には更な る回復を認め再吻合群で $75 \%$, 刺激群では $87 \%$ と健側に近 い回復を認め両者とも切断群と比較して統計学的に有意差 を認めた. 4 週後, 8 週後において刺激群は再吻合群と比 較し高い值であったが統計学的な有意差は認めなかった ( 図 1). また筋全体での筋線維数は各群間において差は認 めず，10倍視野内の筋線維数は筋萎縮により増加，筋線維 断面積の回復により減少を認めた。

2. アセチルコリン受容体数

2 週後では切断群, 再吻合群とも減少を認めたが, 刺激 群では減少すること無く逆に受容体数の有意な増加を認め た. 再吻合群は 4 週後には増加に転じるものの, 8 週後に なると 4 週後と変化は認めなかった. 一方で刺激群では 4 週後から 8 週後までに更なる増加傾向を認めたが, 有意差 は認めなかった (図 2).

アセチルコリン受容体数の変化

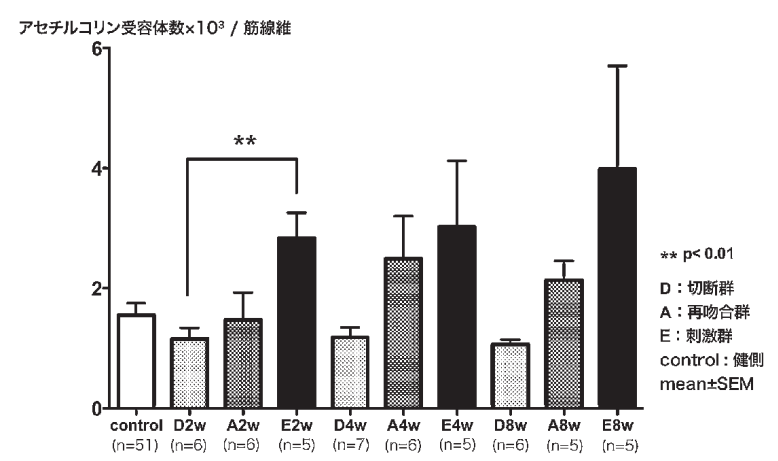

図 2 処置側の筋線維あたりのアセチルコリン受容体 数の変化 2 週後の刺激群で切断群と比較して有意に高値 であった. ( unpaired $\mathrm{t}$ test) 
3 . 神経終末数

2 週後では全ての群において神経終末の存在を認めず， 4 週後から再吻合群, 刺激群ともに神経再生を認めた。 8 週後では光れ光れさらに増加を認め，有意差はないものの 刺激群は再吻合群と比較してより多くの神経終末が再生す る傾向を認めた ( 図 3).

\section{4. 神経筋接合部数}

筋の神経再支配が完了し，再び筋収縮が誘発されるため には, 筋に存在するアセチルコリン受容体と, 再生した神 経終末か接着し, 新たな神経筋接合部が形成されることが 必要である. そここでアセチルコリン受容体全体のなかで, 神経終末と接着し神経筋接合部を形成している割合を算出 した. 4 週後のアセチルコリン受容体のうち再吻合群では $18 \%$ ，刺激群では $33 \%$ に神経筋接合部の形成を認め， 8 週 後では弚れ光れ $74 \% ， 81 \%$ とさらなる増加を認めた．刺激 群は再吻合群と比較して高い数值を認めたが統計学的有意 差を認めるには至らなかった (図 4).

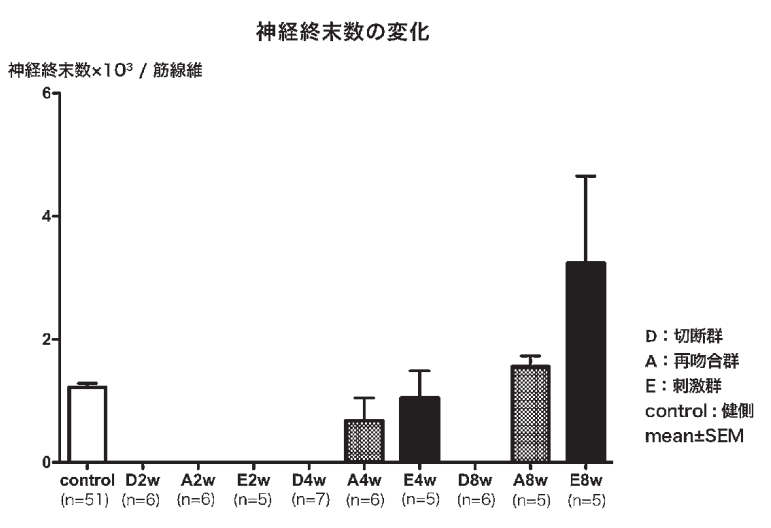

図 3 処置側の筋線維あたりの神経終末数の変化 4 週後から再吻合群, 刺激群において神経再生 を認めた．刺激群は再吻合群と比較してより多 くの神経終末が再生する傾向を認めた.

\section{神経筋接合部形成の割合}

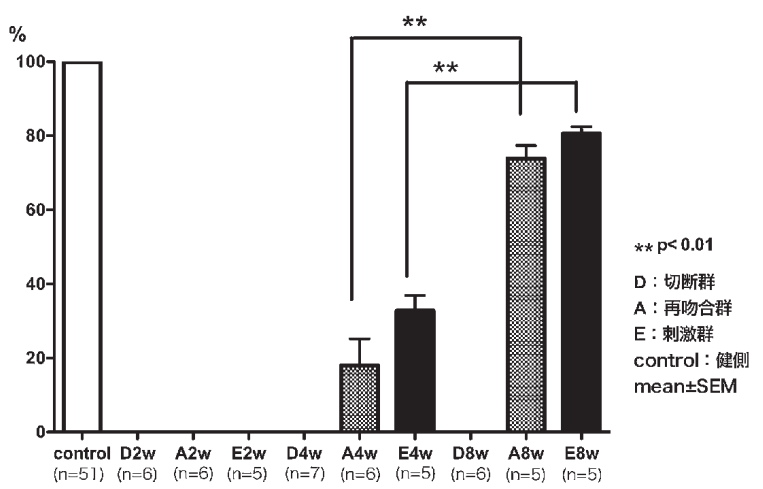

図 4 処置側のアセチルコリン受容体に対する神経終 末数の割合の変化

8 週後の再吻合群, 刺激群は乥れ光れ 4 週後の 同群と比較して有意に高値であった（unpaired $\mathrm{t}$ test)
考察

喉頭は呼吸, 気道反射, 嚥下, 発声などの多彩な機能に 関係する。一䝮性の反回神経麻㾝では一般的に呼吸障害な どの生命に直結する症状は出現しないものの, 患者の QOL に関連した発声機能障害が問題となる.ささらには両 側性の反回神経麻痖では呼吸障害が一番の問題となり，気 管切開, 声帯切除術等の発声機能を犠牲にした治療を選択 せざる得ない場合もある．近年，樣々な神経の障害による 機能障害に対して, 機能的電気刺激 (functional electrical stimulation：FES) を用いた機能回復の試みが注目 されている. 耳鼻咽喉科領域での機能回復の手法としては, 聴覚機能を回復させる人工内耳がすでに一般的な手技とし て確立している.さらに, FES は感覚機能補助のみなら ず, 運動機能補助に関しても応用され, 耳鼻咽喉科領域で は, 顔面神経麻瘏や反回神経麻瘏に対する運動機能回復へ の応用が検討されている. 反回神経麻瘏に対する FES で は両側反回神経麻痺により呼吸障害を起こした患者の一側 の後輪状披裂筋に FES を加える喉頭ペーシングの手技に より，声門を一定のサイクルで開大させ，気管孔の閉鎖が 可能になった症例の報告もされている ${ }^{4,5)}$. また最近では イヌを用いた実験で，内喉頭筋の刺激に適した小さな電極 を用いた両側の喉頭ペーシングによって，より効率的な声 門開大運動を誘発することが可能となったことが報告され ている6).

一方で FES は，失われた運動機能を回復させるだけで はなく, 脱神経後の筋に加える電気刺激の効果により, 筋 の萎縮性変化を抑制することや $\left.{ }^{7}, 8\right)$ ，神経再支配を促進す る可能性があることにも注目されている3，9，10)。これは， 脱神経後の筋に加える電気刺激が FES として運動機能を 回復させるばかりではなく, 筋萎縮抑制, 神経再支配にも 有効的な治療手段となる可能性を示唆するものである. 兴 こで今回我々は，FES が特に神経再支配に与える影響に 関して注目し, ラットの下肢を用いて坐骨神経切断後に吻 合を行った筋に電気刺激を加え，筋線維の形態変化と神経 筋接合部の変化の検討を行った.

以前に我々は筋線維の変化に関してラットの喉頭を用い て，脱神経後の甲状披裂筋に FES を加えることで筋萎縮 性変化を抑制することが可能であること明らかにしてい $3^{11}$. また Zealear らは，イヌの後輪状披裂筋に長期間 FES を加えつづけることで筋萎縮が抑制できたことを報 告している ${ }^{8)}$. 今回のラットの下肢を用いた実験でも，電 気刺激を加えた刺激群は， 2 週間後には一時健側の約 $60 \%$ 程度に筋線維の萎縮を認めるものの, 兴の後回復し 8 週後 には健側とほぼ同樣の值を示した。電気刺激が筋萎縮抑制 の効果があることが再確認される結果であつたが，さらに 効果的な結果を得るためには，刺激パラメータや刺激を与 える時間, 時期, 期間などについてはより詳細な検討が必 要であると考えられた.

今回は, さらに電気刺激が神経筋接合部の再形成に与え 
る影響についても検討をおこなつた．神経筋接合部は節前 である神経終末と節後のアセチルコリン受容体で形成され る.ラットのヒラメ筋を用いた実験 ${ }^{11}$ では，アセチルコ リン受容体数は脱神経後, 約 10 日後から減少し約 2 ヶ月で 半減するが, 脱神経直後より $100 \mathrm{~Hz}$ の電気刺激を加える 事で，光の数を減少させる事無く維持されたことが報告さ れている. 今回の実験では, 電気刺激の条件が異なるもの の, 刺激群で 2 週後, 4 週後, 8 週後と徐々に増加傾向を 認めた. アセチルコリン受容体の発現の制御の一つとして, 伸張してくる神経終末自身より神経放出因子 (Neural Agrin) が分泌され, 脱神経後に不安定な状態となったア セチルコリン受容体が疑集し, 新たな安定化したアセチル コリン受容体を形成することが報告されている ${ }^{12)}$. しかし 脱神経後に神経終末は48時間程度で急速に消失することが 知られており ${ }^{13)}$, 少なくともこの脱神経後48時間の時点か ら神経再支配が起こるまでの期間には, 神経終末由来の神 経放出因子以外の制御機構か働いていると推察される. 近 年, 筋細胞の側にもアセチルコリン受容体の発現を制御し ているMuSK (Muscle Specific Kinase) が存在するこ とが注目されている. Kim らは, 神経放出因子の存在し ない状態では, MuSK がアセチルコリン受容体の発現を 制御し，神経再支配を誘導することを報告している ${ }^{14)}$ ．今 後, 脱神経後に筋に加える電気刺激が MuSK に与える影 響についての詳細な検討が必要であると思われる.

神経筋接合部の節前である神経終末に関して, 現在まで に FES が脱神経後の神経再生に与える影響に関してさま ざまな検討がなされている．しかし神経再支配を促進する 報告がある一方で，再支配を阻害する報告もあり ${ }^{8,15)}$ 依 然として議論のあるところである. 今回の検討では, 刺激 群では, 2 週間後では他の群と同樣に神経終末の存在を認 めず，再支配に要する時間が短縮されているとは考えにく い結果であった. しかし 4 週後, 8 週後には再吻合群と比 較し, 弚の数か増加しており, 神経再生が促進されている 傾向を認めた．神経再支配を促進するとの報告のなかには 分子生物学的手技により詳しい解析がなされているものも あり, ラットの大腿神経を脱神経直後に 1 時間のみ $40 \mathrm{~Hz}$ の電気刺激を加えることにより，神経栄養因子の一つであ る BDNF (brain-derived neurotrophic factor) の発現 か増加するとの報告もある ${ }^{16)}$. また脱神経後の筋線維に残 存しているアセチルコリン受容体に向かって神経再支配が 進んでいくという報告もあり ${ }^{12)}$ ，脱神経後の FES によっ てアセチルコリン受容体がより高率に維持されることが神 経再支配を促進している可能性も考えられる.

アセチルコリン受容体に再生した神経終末が結合した状 態で形成される神経筋接合部の割合は，有意ではないもの の刺激群の方が再吻合群より高い值を示していた．これは 脱神経後に筋に加える電気刺激が神経再支配に促進的に働 くことを示しているものと考えられ, 速やかな再支配の確 率を誘導する手段として有効である可能性を示唆するもの であった. しかし電気刺激に用いる周波数, 強度, 刺激期
間など刺激手段の変化が再支配にどのように影響を与える のか, またより分子生物学的な詳細な基礎的研究を行うこ とで, 今後さらに良好な結果を得ることが可能と思われ， 今後の更なる検討が必要である.

$$
\text { ま と め }
$$

脱神経後の筋に加える機能的電気刺激による神経筋接合 部の変化についての検討を, ラットの下肢をモデルとして 免疫組織学的手法にて検討した. アセチルコリン受容体数, 神経終末ともに刺激を加えた群で, 神経吻合のみを行った 群と比較して高い傾向を認めた．機能的電気刺激か機能回 復, 筋萎縮抑制のみならず, 神経再支配の誘導にも効果的 に働き，この点においても治療手段として有効である可能 性を示唆するものであった.

本論文の要旨は, 第20回日本喉頭科学会学術講演会 (佐 賀)にてて演した.<smiles>[Z19]</smiles>

1) 片田彰博, 野中 聡, 國部 勇ほか：脱神経後の内 喉頭筋萎縮に対する機能的電気刺激の効果. 日気食 会報 $54: 270 \sim 276,2003$.

2) Katada $A$, Nonaka $S$, Adachi $M$ et al : Functional electrical stimulation of laryngeal adductor muscle restores mobility of vocal fold and improves voice sounds in cats with unilateral laryngeal paralysis. Neurosci Res 50 : 153 159, 2004.

3) Zealear DL, Rodriguez RJ, Kenny $\mathrm{T}$ et al : Electrical stimulation of a denervated muscle promotes selective reinnervation by native over foreign motoneurons. J Neurophysiol 87 : 2195 2199, 2002.

4) Zealear DL, Rainey CL, Herzon GD et al : Electrical pacing of the paralyzed human larynx. Ann Otol Rhinol Laryngol 105 : 689 693, 1996.

5) Zealear DL, Swelstad MR, Sant'Anna GD et al : Determination of the optimal conditions for laryngeal pacing with the Itrel II implantable stimulator. Otolaryngol Head Neck Surg 125 : 183 192, 2001.

6) Katada A, Van Himbergen D, Kunibe I et al : Evaluation of a deep brain stimulation electrode for laryngeal pacing. Ann Otol Rhinol Laryngol $117: 621 \sim 629,2008$.

7) Kidd GL : Electrical stimulation for disuse muscle atrophy. Lancet $2: 1025,1988$.

8) Zealear DL, Billante CR, Chongkolwatana $\mathrm{C}$ et al : The effects of chronic electrical stimulation 
on laryngeal muscle physiology and histochemistry. ORL J Otorhinolaryngol Relat Spec $62: 81 \sim 86,2000$.

9) Al-Majed AA, Neumann CM, Brushart TM et al : Brief electrical stimulation promotes the speed and accuracy of motor axonal regeneration. J Neurosci 20 : 2602 2608, 2000.

10) Brushart TM, Hoffman PN, Royall RM et al : Electrical stimulation promotes motoneuron regeneration without increasing its speed or conditioning the neuron. J Neurosci 22 : 6631 6638, 2002.

11) Andreose JS, Fumagalli G, Lomo T : Number of junctional acetylcholine receptors: control by neural and muscular influences in the rat. $\mathrm{J}$ Physiol 483( Pt 2) : 397〜406, 1995.

12) Nguyen QT, Sanes JR, Lichtman JW : Preexisting pathways promote precise projection patterns. Nat Neurosci 5 : 861 867, 2002.

13) Winlow W, Usherwood PN : Ultrastructural studies of normal and degenerating mouse neuromuscular junctions. J Neurocytol 4 : 377 394, 1975.

14) Kim N, Burden SJ : MuSK controls where motor axons grow and form synapses. Nat Neurosci 11 : 19 27, 2008.

15) Zealear DL, Billante CL, Chongkolwatana C et al : The effects of chronic electrical stimulation on laryngeal muscle reinnervation. ORL J Otorhinolaryngol Relat Spec 62 : 87 95, 2000.

16) Al-Majed AA, Brushart TM, Gordon T : Electrical stimulation accelerates and increases expression of $\mathrm{BDNF}$ and trkB mRNA in regenerating rat femoral motoneurons. Eur J Neurosci 12 : 4381 4390, 2000.

\section{別刷請求先 テ 078-8510 北海道旭川市緑が丘東 2 条 1 丁目 1 番 1 号}

旭川医科大学耳鼻咽喉科・頭頸部外科学教室

野村研一郎 